\title{
KONSEP HARTA BERSAMA DAN IMPLEMENTASINYA DI PENGADILAN AGAMA
}

\author{
Mesraini \\ Fakultas Syariah dan Hukum UIN Syarif Hidayatullah Jakarta \\ Jl. Ir. H. Juanda 95, Ciputat, Jakarta \\ E-mail: mesraini@yahoo.com
}

\begin{abstract}
The Concept of Joint Assets and its Implementation in the Religious Court. Legislation in Indonesia stipulates that any property acquired during marriage becomes joint property of husband and wife, without distinguishing who works and who registered the property. If the marriage come to an ends, either through death or divorce, the property must be divided equally. In general, this study found that a panel of judges in the religious court division decided a case of the distribution of joint property is not outside of the statutory rules. Since no agreement or reconciliation had been made by the husband and wife in dispute about the portion of the division of their property, the judge decided that the joint property be divided in the same amount. However, if there is an agreement between husband and wife, the division of the joint property will be based on that agreement.
\end{abstract}

Keywords: community property, Compilation of Islamic Law, judgment, Court of Religion.

\begin{abstract}
Abstrak: Konsep Harta Bersama dan Implementasinya di Pengadilan Agama. Perundang-undangan di Indonesia mengatur bahwa setiap harta yang diperoleh selama perkawinan dijadikan sebagai harta bersama suami isteri, tanpa membedakan siapa yang bekerja dan harta itu terdaftar atas nama siapa. Apabila perkawinan itu berakhir, baik karena kematian maupun karena perceraian, maka harta tersebut harus dibagi dua sama banyak nilainya. Penelitian ini menemukan data bahwa secara umum majelis hakim Pengadilan Agama dalam memutuskan perkara pembagian harta bersama tidak keluar dari aturan perundang-undangan tersebut. Selama tidak ada kesepakatan atau perdamaian yang dibuat oleh suami dan isteri yang bersengketa tentang porsi pembagian harta bersama, majelis hakim memutuskan harta bersama tersebut dibagi sama banyak. Namun, apabila terdapat kesepakatan antara suami dan isteri, pembagian harta bersama didasarkan atas kesepakatan yang mereka buat.
\end{abstract}

Kata Kunci: harta bersama, Kompilasi Hukum Islam, putusan hakim, Pengadilan Agama

\section{Pendahuluan}

Perceraian merupakan peristiwa hukum yang menimbulkan serangkaian akibat-akibat hukum, antara lain pembagian harta kekayaan yang diperoleh selama perkawinan. Pembagian harta kekayaan itu merupakan bagian krusial pasca perceraian. Hal ini dapat dicermati dari banyaknya kasus yang menarik perhatian publik terhadap pembagian harta perkawinan. Pertama, kasus perceraian artis Dewi Huges dengan mantan suaminya yang pernah menjadi berita besar di pelbagai media. Gugatan cerai Hughes dikabulkan oleh Pengadilan Agama Jakarta Selatan. Pengadilan Agama menetapkan bahwa pembagian harta bersama atau gono gini adalah 50:50. Atas keputusan tersebut Dewi Huges melakukan upaya hukum banding. ${ }^{1}$ Kedua, putusan perceraian dan pembagian harta perkawinan yang tragis di Surabaya,

${ }^{1}$ http://suaramerdeka.com/harian/05/05/10/bud05.html, 10 Mei 2005, diunduh pada 17 Februari 2011. di mana seorang Kolonel Angkatan Laut membunuh Hakim dan mantan isterinya dengan sangkur setelah putusan pembagian harta dibacakan. ${ }^{2}$

Beberapa peristiwa di atas menunjukkan bahwa pembagian harta bersama merupakan peristiwa hukum yang signifikan. Memang, biasanya pasangan yang akan melakukan perkawinan jarang memikirkan persoalan mengenai kedudukan harta bawaan masing-masing pihak serta kedudukan harta yang diperoleh setelah perkawinan mereka, karena pada awal perkawinan tidak ada pasangan yang berfikir untuk bercerai. Terhadap pasangan yang demikian harus tunduk kepada aturan yang telah dimuat dalam UU No. 1 Tahun 1974 tentang Perkawinan Pasal 35 ayat (1)selanjutnya disebut Undang-undang Perkawinan, yang menyatakan, "Harta benda yang diperoleh sepanjang

2 http://m.detik.com, 22 September 2005, diunduh pada 17 Februari 2011. 
perkawinan menjadi harta bersama”.

Selanjutnya, Pasal 37 Undang-undang Perkawinan menentukan, "Bila perkawinan putus karena perceraian, harta bersama diatur menurut hukumnya masing-masing." Dalam penjelasan Pasal 37 tersebut dikatakan bahwa yang dimaksud dengan "hukumnya masing-masing" ialah hukum agama, hukum Adat, dan hukum-hukum lainnya. Dengan demikian, bagi orang Islam berlaku ketentuan hukum yang terdapat dalam Kompilasi Hukum Islam (selanjutnya disingkat: KHI). Pasal 96 ayat [1] KHI menjelaskan, "Apabila terjadi cerai mati, maka separoh harta bersama menjadi hak pasangan yang hidup lebih lama." Kemudian dalam pasal 97 ditentukan, "Janda atau duda cerai hidup masing-masing berhak seperdua dari harta bersama sepanjang tidak ditentukan lain dalam perjanjian perkawinan."

Aturan-aturan yang dimuat dalam KHI tentang harta bersama cenderung menghendaki pembagian yang adil bagi suami dan isteri dengan membagi dua sama besar, terlepas dari siapa yang mengusahakan harta bersama tersebut. Namun demikian, keadilan yang diharapkan oleh KHI dengan membagi sama besar terhadap harta bersama belum tentu dirasakan adil oleh pihak yang berperkara. Sebab, sekalipun KHI tidak memperhatikan harta tersebut atas upaya siapa dan atas nama siapa, dalam kenyataannnya di masyarakat masih banyak yang tidak bisa melepaskan jasa-jasanya selama perkawinan. Sikap itulah yang memicu perselisihan dan perasaan "dirugikan" dengan adanya pembagian harta bersama tersebut.

Keadaan yang demikian merupakan sebuah masalah yang patut mendapatkan perhatian serius. Hakim-hakim yang menyelesaikan perkara gugatan harta bersama ini mampu memberikan win-win solution bagi para pencari keadilan. Di sinilah letak keseimbangan yang diharapkan antara law in book dengan law in action. Bagaimana hakim menyikapi pelbagai kasus gugatan harta bersama yang diajukan ke Pengadilan. Hal inilah yang mendorong peneliti untuk mengetahui lebih jauh apakah ketentuan pembagian harta bersama dalam KHI itu digunakan secara mutlak? Apakah semua kasus harta bersama diselesaikan dengan pembagian fifty-fifty atau ada solusi lain yang ditawarkan Majelis Hakim dengan memberikan porsi lebih besar kepada suami dan isteri yang memberikan sumbangsih pekerjaan yang lebih banyak? Untuk menjawab masalah itulah studi ini dilakukan.

\section{Harta Bersama dalam Peraturan Perkawinan di Indonesia}

Ketentuan hukum tentang harta kekayaan suami dan isteri dalam suatu perkawinan diatur dalam Undang- undang Perkawinan dan KHI. Dalam Undang-undang Perkawinan, hal tersebut diatur pada Pasal 35-37 dan Pasal 65, sedangkan dalam KHI diatur pada Pasal 8597.

Menurut peraturan perundang-undangan yang berlaku di Indonesia, harta kekayaan suami isteri dalam perkawinan dapat dibagi menjadi dua jenis. Pertama, harta bersama, yaitu semua harta kekayaan yang diperoleh selama ikatan pernikahan, baik oleh suami saja, isteri saja, atau keduanya, ${ }^{3}$ kecuali harta yang diperoleh melalui hibah, hadiah, dan warisan yang diperuntukkan khusus untuk individu suami atau isteri. Harta bersama dapat berupa benda berwujud atau tidak berwujud. Harta bersama yang berwujud dapat meliputi benda tidak bergerak, benda bergerak, dan surat-surat berharga. Sedangkan harta bersama yang tidak berwujud dapat berupa hak maupun kewajiban. ${ }^{4}$

Kedua, harta milik pribadi masing-masing suami isteri, yaitu harta yang telah dimiliki oleh masingmasing suami atau isteri sebelum mereka menikah (sering disebut juga dengan harta bawaan) atau harta yang diperoleh masing-masing suami isteri dalam ikatan pernikahan melalui hibah, hadiah, dan warisan yang diperuntukkan khusus buat yang bersangkutan.

Pembagian tersebut dipahami dari aturan Pasal 35 Undang-undang Perkawinan sebagai berikut:

(1) Harta benda yang diperoleh selama perkawinan menjadi harta bersama.

(2) Harta bawaan dari masing-masing suami dan isteri dan harta benda yang diperoleh masing-masing sebagai hadiah atau warisan, adalah di bawah penguasaan masing-masing sepanjang para pihak tidak menentukan lain.

Selanjutnya aturan tentang harta kekayaan dalam perkawinan itu dipertegas lagi dalam KHI pasal 85-87, yang berbunyi:

Pasal 85: Adanya harta bersama dalam perkawinan itu tidak menutup kemungkinan adanya harta milik masing-masing suami atau isteri.

Pasal 86: (1) Pada dasarnya tidak ada percampuran antara harta suami dan harta isteri karena perkawinan.

(2) Harta isteri tetap menjadi hak isteri dan dikuasai penuh olehnya, demikian juga harta suami tetap menjadi hak suami dan dikuasai penuh olehnya.

Pasal 87. (1) Harta bawaan dari masing-masing suami

${ }^{3}$ KHI Pasal 1 huruf [f] menyebutkan, "Harta kekayaan dalam perkawinan atau syirkah adalah harta yang diperoleh baik sendiri-sendiri atau bersama suami isteri selama dalam ikatan perkawinan berlangsung dan selanjutnya disebut harta bersama, tanpa mempersoalkan terdaftar atas nama siapapun."

${ }^{4}$ KHI Pasal 91 ayat (1): "Harta bersama sebagaimana tersebut dalam pasal 85 di atas dapat berupa benda berwujud atau tidak berwujud". Ayat (2): "Harta bersama yang berwujud dapat meliputi benda tidak bergerak, benda bergerak dan surat-surat berharga." Ayat (3): "Harta bersama yang tidak berwujud dapat berupa hak maupun kewajiban." 
dan isteri dan harta yang diperoleh masing-masing sebagai hadiah atau warisan adalah di bawah penguasaan masing-masing, sepanjang para pihak tidak menentukan lain dalam perjanjian perkawinan. (2) Suami dan isteri mempunyai hak sepenuhnya untuk melakukan perbuatan hukum atas harta masing-masing berupa hibah, hadiah, sadaqah, dan lainnya.

Baik Undang-undang Perkawinan maupun KHI mengakui adanya percampuran harta bersama suami dan isteri secara terbatas. Dikatakan secara terbatas karena harta kekayaan yang bersatu dalam perkawinan itu adalah harta kekayaan yang hanya diperoleh melalui usaha suami dan isteri selama dalam perkawinan, tidak termasuk harta pemberian berupa hadiah atau warisan yang diperoleh suami atau isteri meskipun didapatkan masih dalam ikatan perkawinan. Begitu pula harta bawaan yang dibawa masing-masing suami dan isteri ke dalam perkawinan tidak dimasukkan sebagai harta bersama.

Namun demikian, apabila diamati secara teliti, terdapat perbedaan aturan antara Undang-undang Perkawinan dengan KHI tentang kapan harta pencarian suami dan isteri dipandang sebagai harta bersama. Menurut Undang-undang Perkawinan, pada dasarnya harta dalam perkawinan itu terbagi dua macam: harta bersama dan harta pribadi. Harta pribadi dapat berubah statusnya menjadi harta bersama jika suami dan isteri membuat perjanjian yang mereka sepakati bersama yang isinya bahwa semua harta pribadi baik yang sudah ada sebelum perkawinan dilangsungkan maupun setelah akad perkawinan akan menjadi harta bersama yang dikuasai secara bersama-sama pula. Tanpa adanya perjanjian yang mereka sepakati, harta pribadi tetap terpisah dan dikuasai oleh masing-masing suami dan isteri. Sedangkan harta pencarian otomatis menjadi harta bersama.

Menurut KHI, pada dasarnya tidak ada percampuran harta suami dan harta isteri dalam perkawinan. Harta isteri tetap menjadi harta isteri dan harta suami tetap menjadi harta suami. Namun demikian, suami dan isteri dapat saja membuat perjanjian perkawinan yang disepakati bersama tentang percampuran harta pribadi dan pemisahan harta pencarian masing-masing. ${ }^{5}$ Tanpa adanya perjanjian yang mereka sepakati, harta pribadi maupun harta pencarian akan tetap menjadi harta pribadi. Dengan demikian, konsep harta bersama dalam sebuah perkawinan baru dapat terwujud jika dibuat

${ }^{5}$ KHI Pasal 47 ayat (1): "Pada waktu atau sebelum perkawinan dilangsungkan kedua calon mempelai dengan membuat perjanjian tertulis yang disahkan Pegawai Pencatat Nikah mengenai kedudukan harta dalam perkawinan." Ayat (2), "Perjanjian tersebut pada ayat (1) dapat meliputi percampuran harta pribadi dan pemisahan harta pencaharian masing-masing sepanjang hal itu tidak bertentangan dengan hukum Islam." melalui perjanjian perkawinan terlebih dahulu.

Setelah menjelaskan tentang macam-macam harta benda dalam perkawinan, Undang-undang Perkawinan dan juga KHI menguraikan tentang penggunaan (tasharruf) dari kedua jenis harta dalam perkawinan tersebut. Suami dan isteri memiliki hak dan kewajiban yang sama untuk menggunakan dan menjaga harta bersama sesuai dengan persetujuan kedua belah pihak. ${ }^{6}$ Sedangkan harta kekayaan milik pribadi suami atau milik pribadi isteri dikuasai penuh oleh masing-masing suami atau isteri sebagai pemilik. Masing-masing pemilik mempunyai hak sepenuhnya untuk melakukan perbuatan hukum apa saja atas harta pribadinya tersebut. ${ }^{7}$ Namun demikian, masing-masing suami maupun isteri berkewajiban pula untuk menjaga harta pribadi pasangannya. ${ }^{8}$

Apabila terjadi perselisihan antara suami dan isteri tentang harta bersama, maka penyelesaian perselisihan itu diajukan ke Pengadilan Agama. ${ }^{9}$ Bahkan, apabila salah satu pihak melakukan perbuatan yang dapat merugikan dan membahayakan harta bersama, seperti pemboros, penjudi, pemabuk, dan sebagainya, maka pihak yang lain dapat meminta Pengadilan Agama untuk meletakkan sita jaminan atas harta bersama tersebut, meskipun mereka tidak mengajukan perceraian. ${ }^{10}$

Dalam peraturan perundang-undangan di Indonesia juga diatur tentang harta bersama dalam bentuk perkawinan poligami. Isteri kedua dan seterusnya tidak mempunyai hak atas harta bersama yang telah ada sebelum perkawinan dengan isteri kedua atau

\footnotetext{
${ }^{6}$ Undang-undang Nomor 1 Tahun 1974 Pasal36 ayat (1): "Mengenai harta bersama, suami atau isteri dapat bertindak atas persetujuan kedua belah pihak." Lihat juga KHI Pasal 89: "Suami bertanggung jawab menjaga harta bersama, harta isteri maupun hartanya sendiri." Selanjutnya KHI Pasal 90: "Isteri turut bertanggung jawab menjaga harta bersama maupun harta suaminya yang ada padanya." Begitu juga dengan KHI Pasal 92: "Suami atau isteri tanpa persetujuan pihak lain tidak diperbolehkan menjual atau memindahkan harta bersama."

Undang-undang Nomor 1 Tahun 1974 Pasal 36 ayat (2): "Mengenai harta bawaan masing-masing, suami dan isteri mempunyai hak sepenuhnya untuk melakukan perbuatan hukum mengenai harta bendanya." Lihat juga KHI Pasal 86 ayat (2): "Harta isteri tetap menjadi hak isteri dan dikuasai penuh olehnya, demikian juga harta suami tetap menjadi hak suami dan dikuasai penuh olehnya." Begitu juga KHI Pasal 87 ayat (2): "Suami dan isteri mempunyai hak sepenuhnya untuk melakukan perbuatan hukum atas harta masing-masing berupa hibah, hadiah, sedekah, dan lainnya."

${ }^{8}$ Lihat KHI Pasal 89 dan 90 seperti telah dikutip terdahulu.

${ }^{9}$ KHI Pasal 88.

${ }^{10}$ KHI Pasal 95 ayat (1): "Dengan tidak mengurangi ketentuan Pasal 24 ayat (2) huruf c peraturan Pemerintah No. 9 Tahun 1975 dan Pasal 136 ayat (2): suami atau istri dapat meminta Pengadilan Agama untuk meletakkan sita jaminan atas harta bersama tanpa adanya gugatan cerai, apabila salah satu melakukan perbuatan yang merugikan dan membahayakan harta bersama seperti judi, mabuk, boros dan sebagainya." Ayat (2): "Sebelum masa sita dapat dilakukan penjualan atas harta bersama untuk kepentingan keluarga dengan izin Pengadilan Agama."
} 
berikutnya itu terjadi. Dengan demikian, dalam perkawinan poligami akan terbentuk beberapa harta bersama suami dan isteri, tergantung berapa orang suami memiliki isteri. Jika seorang suami memiliki dua orang isteri, maka dalam perkawinan tersebut ada dua macam harta bersama, di mana antara yang satu dengan yang lainnya terpisah. Harta bersama yang telah ada pada perkawinan pertama terpisah dengan harta bersama pada perkawinan kedua, dan seterusnya tergantung pada jumlah isteri dalam perkawinan poligami bersangkutan. Artinya, masing-masing harta bersama berdiri sendiri dan terbatas dalam menentukan terbentuknya harta bersama, yaitu dihitung sejak tanggal perkawinan dilangsungkan dengan masingmasing isteri. ${ }^{11}$

Pasal 37 Undang-undang Perkawinan juga menentukan pembagian harta bersama apabila perkawinan putus karena perceraian. Pasal tersebut berbunyi, "Bila perkawinan putus karena perceraian, harta bersama diatur menurut hukumnya masing-masing." Dalam penjelasan Pasal 37 tersebut dinyatakan bahwa yang dimaksud dengan "hukumnya masing-masing" ialah hukum agama, hukum Adat, dan hukum-hukum lainnya. Dengan demikian jelas bahwa bagi orang Islam berlaku ketentuan hukum yang terdapat dalam KHI. Pasal 96 ayat (1) KHI menjelaskan, "Apabila terjadi cerai mati, maka separoh harta bersama menjadi hak pasangan yang hidup lebih lama." Kemudian dalam Pasal 97 KHI ditentukan, "Janda atau duda cerai hidup masing-masing berhak seperdua dari harta bersama sepanjang tidak ditentukan lain dalam perjanjian perkawinan."

\section{Harta Bersama dalam Pandangan Fukaha}

Pembahasan tentang harta bersama dalam kitab-kitab fikih yang ditulis oleh fukaha mazhab tidak ditemukan. Hal ini dimungkinkan karena Alquran dan Hadis tidak membahas secara khusus mengenai pelembagaan harta bersama dalam suatu ikatan perkawinan. Sejauh ini hanya ditemukan ayat-ayat Alquran yang membahas masalah harta benda secara umum, di antaranya Q.s. al-Nisâ' [4]: 32. ${ }^{12}$

Ayat tersebut bersifat umum dan tidak ditujukan

${ }^{11}$ KHI Pasal 94 (1) Harta bersama dari perkawinan seorang suami yang mempunyai isteri lebih dari seorang, masing-masing terpisah dan berdiri sendiri. (2) Pemilikan harta bersama dari perkawinan seorang suami yang mempunyai isteri lebih dari seorang sebagaimana tersebut dalam ayat (1), dihitung pada saat berlangsungnya akad perkawinan yang kedua, ketiga atau yang keempat. Lihat juga Undang-undang Nomor 1 Tahun 1974 Pasal 65 ayat [1] huruf [b] dan [c].

${ }^{12}$ Q.s. al-Nisâ" [4] ayat 32, yang terjemahannya berbunyi, "Dan janganlah kamu iri hati terhadap apa yang dikaruniakan Allah kepada sebahagian kamu lebih banyak dari sebahagian yang lain. (Karena) bagi orang laki-laki ada bahagian daripada apa yang mereka usahakan, dan kepada suami atau isteri saja, melainkan semua lakilaki dan perempuan. Jika seseorang berusaha dalam kehidupannya sehari-hari maka hasil usahanya itu merupakan harta pribadi yang dimiliki dan dikuasai oleh pribadi masing-masing.

Dalam kitab-kitab fikih ditemui pembahasan tentang "متاع البيت" (perabotan rumah tangga). ${ }^{13}$ Dalam pembahasan tersebut fukaha menjelaskan apabila terjadi perselisihan antara suami isteri tentang kepemilikan perlengkapan rumah tangga, baik keduanya telah bercerai maupun belum bercerai, maka untuk menentukan kepemilikan harta tersebut diatur sebagai berikut.

Menurut Imam al-Syâfi $\hat{i}$, suami maupun isteri yang berebut harta berupa perabotan rumah tangga itu disuruh bersumpah. Jika salah satu pihak mau bersumpah dan pihak yang lain tidak mau bersumpah, maka harta yang diperebutkan itu menjadi milik orang yang mau bersumpah. Jika keduanya sama-sama bersumpah, maka harta yang diperebutkan itu dibagi dua, baik harta itu berupa perlengkapan rumah tangga yang biasa dipakai khusus laki-laki, khusus perempuan, maupun yang biasa digunakan bersama. ${ }^{14}$

Menurut Abû Hanîfah dan kelompok Imâmiyyah, untuk menentukan kepemilikan perabotan rumah tangga yang diperebutkan harus diteliti terlebih dahulu apakah perlengkapan itu khusus untuk laki-laki, khusus untuk perempuan, atau bisa dipergunakan bersama. Apabila harta yang diperebutkan berupa perlengkapan rumah tangga yang biasa dipakai laki-laki, maka yang menjadi pemilik harta itu adalah suami, dan suami diminta bersumpah. Begitu juga apabila harta yang diperebutkan berupa perlengkapan rumah tangga yang biasa dipakai perempuan, maka yang menjadi pemilik harta itu adalah isteri, dan isteri diminta bersumpah. Akan tetapi, Abû Hanîfah dan Imâmiyyah berbeda pendapat tentang harta yang diperebutkan itu berupa perlengkapan rumah tangga yang biasa dipergunakan

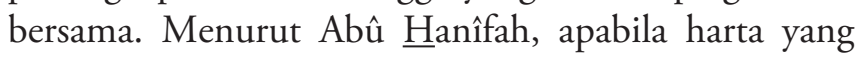
diperebutkan itu berupa harta yang biasa digunakan bersama maka yang menjadi pemiliknya adalah suami. ${ }^{15}$ Sedangkan Imâmiyyah berpendapat apabila harta yang diperebutkan berupa perlengkapan rumah

bagi para wanita (pun) ada bagian dari apa yang mereka usahakan, dan mohonlah kepada Allah sebagian dari karunia-Nya. Sesungguhnya Allah Maha Mengetahui segala sesuatu."

${ }^{13}$ Syams al-Dîn al-Sarakhsî, al-Mabsîth, (Bayrut: Dâr al-Ma rûfah, 1989), Juz 4, h. 101; Al-Imâm Sahnûn ibn Sa'îd al-Tanûkhî, alMudâwanah al-Kubrâ, (Bayrût: Dâr Sadir, 1323 H), Juz 2, h. 187; Muhammad Idrîs al-Syâfi' î, al-Umm,(t.tp: t.p, t.th.), Juz 5, h. 160; Ibn Qudâmah, al-Mughnî wa Syarh al-Kabîr, (Bayrût: Dâr al-Fikr, 1984), Juz 12, h. 225; Lihat juga, Muhammad Jawad Mughniyah, al-Fiqh 'alâ al-Madzâhib al-Khamsah, (Bayrût: Dâr al-Jawad, t.th.), h. 382.

${ }^{14}$ Muhammad Idrîs al-Syâfi'î, al-Umm, Juz 5, h. 160.

${ }^{15}$ Syams al-Dîn al-Sarakhsî, al-Mabsûth..., h. 101. 
tangga yang biasa digunakan bersama, maka harta tersebut dinyatakan sebagai milik pihak yang bisa menunjukkan bukti. Kalau kedua belah pihak tidak bisa menunjukkan bukti, maka masing-masing pihak diminta bersumpah bahwa harta itu miliknya. Sesudah keduanya bersumpah, harta itu dibagi dua. Kalau salah satu pihak bersedia bersumpah sedangkan pihak lain tidak mau bersumpah, maka harta itu diberikan kepada pihak yang bersumpah. ${ }^{16}$

Dari pembahasan fukaha tentang perselisihan kepemilikan perabotan rumah tangga di atas dapat disimpulkan bahwa harta kekayaan suami isteri adalah terpisah. Tidak dikenal istilah harta yang dimiliki bersama. Suami memiliki hartanya sendiri dan isteri juga memiliki hartanya sendiri, baik harta benda yang mereka bawa pada permulaan perkawinan maupun harta yang mereka dapatkan selama perkawinan berlangsung, baik sebagai hasil pekerjaannya sendiri, maupun sebagai penghibahan, hadiah, maupun warisan dari orang lain. Semua harta kekayaan tersebut menjadi milik pribadi suami atau isteri yang dikuasai penuh oleh masingmasing pribadi.

Tidakadanya pelembagaan harta bersama suami isteri dalam suatu ikatan perkawinan dimungkinkan karena suami telah berkewajiban penuh untuk memberikan nafkah kepada keluarga, isteri, dan anak-anaknya. Suamilah yang bertanggung jawab dalam penyediaan sandang, pangan, papan, dan keperluan rumah tangga yang lainnya. Seorang suami tidak boleh menggunakan harta kekayaan milik isterinya, kecuali dengan persetujuan isteri. Apabila suami mempergunakan harta kekayaan milik isterinya sekalipun untuk keperluan belanja rumah tangga, maka suami dipandang berutang kepada isteri dan suami wajib mengembalikannya.

\section{Pembaruan Hukum Islam tentang Konsep Harta Bersama}

Kitab-kitab fikih klasik tidak mengatur tentang pelembagaan harta bersama suami isteri. Menurut fukaha, suami memiliki hartanya sendiri dan isteri juga memiliki hartanya sendiri. Sebagai kewajibannya, suami memberikan sebagian hartanya itu kepada isterinya atas nama nafkah, yang untuk selanjutnya digunakan isteri bagi keperluan rumahtangganya. ${ }^{17} \mathrm{Hal}$ ini berbeda dengan peraturan perundang-undangan perkawinan di Indonesia. Dalam perundang-undangan perkawinan di Indonesia ditemukan aturan tentang pelembagaan

${ }^{16}$ Muhammad Jawad Mughniyah, al-Figh 'alâ al-Madzâhib alKhamsah, h. 382.

${ }^{17}$ Amir Syarifuddin, Hukum Perkawinan Islam di Indonesia; Antara Munakahat dan Undang-undang Perkawinan, (Jakarta: Kencana, 2006), h. 175 . harta bersama.

Yang dimaksud dengan pelembagaan harta bersama adalah penyatuan harta yang diperoleh selama dalam perkawinan untuk menjadi harta berdua suami isteri tanpa menghiraukan siapa yang bekerja dan harta itu terdaftar atas nama siapa. Meskipun yang bekerja hanyalah salah satu pihak suami atau isteri saja, harta yang diperoleh tetap dipandang sebagai harta bersama. Masing-masing suami dan isteri sama-sama berhak mempergunakan harta bersama tersebut. Kemudian, apabila hubungan perkawinan suami dan isteri berakhir, baik karena kematian maupun karena perceraian, maka harta tersebut harus dibagi.

Diaturnya penyatuan harta kekayaan suami dan isteri menjadi harta bersama dalam perundang-undangan di Indonesia, diduga kuat karena pelembagaan harta bersama tersebut telah dikenal lama dan dipraktikkan dalam kesadaran kehidupan sehari-hari masyarakat Islam di Indonesia. Pelembagaan harta bersama telah dikenal sejak dulu dalam hukum adat di Indonesia. Hukum adat tentang harta bersama telah diterapkan dan terusmenerus sebagai hukum yang hidup di negara ini.

Meskipun kitab fikih klasik tidak membicarakan pelembagaan harta bersama, tidak berarti melarangnya. Ketiadaan pembahasan mungkin dipengaruhi oleh faktor struktur sosial, politik, budaya, dan letak geografis tempat fukaha hidup. Padahal, keberadaan ketentuan harta bersama di masa kini sangat dibutuhkan dalam perundang-undangan perkawinan Islam di Indonesia. Ini merupakan salah satu materi hukum Islam yang mengalami pembaruan. Ada beberapa pendekatan yang bisa dipakai dalam melakukan pembaruan hukum Islam seputar harta bersama ini.

Pertama, Alquran dan Hadis tidak ada yang memerintahkan tentang harta kekayaan bersama suami dan isteri dalam perkawinan, dan juga sebaliknya, tidak ada pula larangan percampuran harta kekayaan suami dan isteri dalam perkawinan. Berdasarkan tidak ada perintah dan larangan tersebut, menurut hukum, dapat dirumuskan di dalam suatu kaidah, "Sesuatu yang tidak ada larangan adalah boleh untuk dikerjakan". Dengan demikian, secara hukum pelembagaan harta kekayaan bersama suami dan isteri seperti yang diatur dalam perundang-undangan perkawinan Indonesia boleh dilakukan.

Kedua, praktik harta bersama suami isteri dalam perkawinan di Indonesia telah lama ada, seiring dengan ketentuan hukum Adat yang hidup pada masingmasing wilayah. Dikenalnya istilah Hareuta Sihareukat di Aceh, Gono-gini di Jawa, Cakkara di Bugis dan Makasar, Barang Perpantangan di Kalimantan, Guna Kaya di Sunda, Druwe Gabro di Bali, dan sebagainya, menunjukkan bahwa konsep harta bersama telah lama 
dipraktikkan oleh masyarakat adat di Indonesia. ${ }^{18}$ Berkaitan dengan ini, ada sebuah kaidah yang bisa digunakan, yakni:

$$
\text { العادة محكمة } 19
$$

"Aturan yang sudah ada dalam masyarakat dapat dijadikan hukum."

Kaidah tersebut didasarkan atas Hadis Rasulullah Saw. yang diriwayatkan oleh Imam Ahmad:

$$
\text { ما راه المسلمون حسنا فهو عند الله حسن } 20
$$

"Apa yang dianggap baik oleh orang muslim, maka baik pula menurut Allah."

Ketiga, terdapatnya konsep harta bersama sebagai syirkah ${ }^{21}$ dalam fikih muamalah. Harta bersama merupakan bentuk persekutuan antara suami dan isteri. Jika yang bekerja hanya salah satu pihak, suami atau isteri saja, maka dinamakan dengan syirkah abdân, dan jika yang bekerja adalah suami dan isteri, maka dinamakan syirkah 'inân. Ismuha menuliskan bahwa harta pencarian suami dan isteri masuk dalam

${ }^{18}$ Imam Sudiyat, Hukum Adat: Sketsa Asas, (Yogyakarta: Liberty, 1981), h. 148.

19 Jalâl al-din al-Suyûthî, al-Asybâh wa al-Nazhẩir fî Qawâ'id wa Furû' al-Fiqh al-Syâfi $\hat{\imath}$, (al-Qâhirah: Isa al-Bâbi al-Halabi, t.th), h. 191.

20 al-Imâm Ahmad ibn Hanbal, Musnad al-Imâm Ahmad, (Bayrut: Dâr al-Fikr, t.th), Juz 1, h. 279.

${ }^{21}$ Dalam fikih muamalah, syirkah terbagi menjadi lima bentuk. Pertama, Syarîkah al-inân (perkongsian terbatas), yaitu dua orang atau lebih melakukan perkongsian dengan masing-masing harta mereka untuk bersama-sama mengelola, kemudian keuntungan dan kerugiannya dibagi di antara mereka. Dalam syirkah ini tidak ada persyaratan harus sama di dalamnya, baik mengenai modal, pengelolaan, maupun pembagian keuntungannya. Mayoritas ulama sependapat tentang bolehnya perkongsian tersebut. Kedua, Syarîkah al-mufâwadhah (perkongsian tak terbatas), yaitu perkongsian antara dua orang atau lebih sebagai gabungan dari semua bentuk perkongsian. Posisi dan komposisi pihak-pihak yang terlibat di dalamnya adalah tidak sama, baik dalam hal modal, pekerjaan maupun dalam hal keuntungan dan kerugian. Ketiga, Syarîkah al-abdân (perkongsian tenaga), yaitu perkongsian yang dilakukan oleh para pekerja antara dua orang atau lebih untuk menerima dan mengerjakan suatu pekerjaan dengan tenaga masing-masing, dan kemudian membagi hasil jerih payahnya sesuai dengan perjanjian yang telah mereka tetapkan. Dengan kata lain mereka mengadakan perkongsian dalam pekerjaan yang mereka lakukan dengan tangantangan mereka atau dengan tenaga mereka. Seperti melakukan pekerjaan tertentu, baik kerja pemikiran maupun pekerjaan yang bersifat fisik. Hukumnya boleh menurut mazhab ㅂanafî, Mâlikî

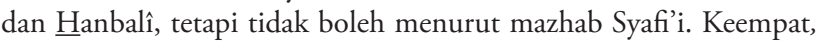
Syarîkah al-wujûh (perkongsian kepercayaan), yaitu kerja sama antara dua orang atau lebih dengan modal pihak luar. Artinya ada pihak ketiga yang memberikan modalnya sehingga kedua orang tersebut mendapatkan keuntungan dari modal pihak lain. Kelima, Syarîkah al-mudhârabah yaitu kerja sama antara pemilik modal di satu pihak dan pekerja pada pihak lain, yang keuntungan dibagi berdasarkan kesepakatan, sedangkan kerugian ditanggung oleh pihak pemberi modal. syirkah al-abdân al-mufâwadhah. Alasannya adalah bahwa kenyataan pada umumnya suami dan isteri dalam masyarakat Indonesia, sama-sama bekerja membanting tulang untuk berusaha mendapatkan nafkah hidup keluarga sehari-hari dan sekadar untuk simpanan masa tua mereka. Suami isteri sama-sama bekerja untuk mencari nafkah rumah tangganya, hanya saja karena fisik isteri berbeda dengan fisik suami, maka dalam kerja sama tersebut, mereka membagi tugas sesuai dengan perbedaan fisik. Kalau suami isteri tersebut berprofesi sebagai petani, maka suami mendapat pekerjaan seperti, menggarap dan membajak sawah, mencangkul dan lain sebagainya yang merupakan pekerjaan yang membutuhkan kekuatan fisik, sedangkan isteri mendapatkan pekerjaan mengurus rumah tangga, mengasuh anak-anak, dan sebagainya yang merupakan pekerjaan yang kurang membutuhkan kekuatan fisik atau yang bersifat jasmani. ${ }^{22}$

Dengan demikian dapat disimpulkan bahwa pelembagaan harta bersama suami isteri dalam perkawinan sebagaimana diatur dalam perundangundangan perkawinan di Indonesia diperlukan sebagai salah satu upaya perlindungan terhadap para perempuan (isteri). Sebab, sebelum pelembagaan harta bersama itu terbentuk, kedudukan isteri seakanakan tidak mempunyai peran signifikan dalam sebuah rumah tangga. Posisi isteri cenderung terpinggirkan dan tidak memiliki kekuatan dalam memperjuangkan hak-haknya. Dengan adanya pelembagaan ini, hak dan kedudukan suami isteri dalam rumah tangga menjadi seimbang dengan kewajiban-kewajibannya, dalam pengertian saling mengisi kekurangan masingmasing tanpa ada diskriminasi. Sesuatu hal yang oleh ketentuan hukum Islam tidak dijelaskan atau tidak diatur secara qath'̂े (pasti), maka diberikan kelonggaran kepada umatnya untuk berkreasi dan berinovasi untuk menciptakan hukum serta menggali hukum dari apa yang telah hidup dalam masyarakat, yaitu menciptakan hukum yang lebih sesuai dengan kondisi dan situasi masyarakat tertentu, seperti Indonesia.

\section{Pelaksanaan Pembagian Harta Bersama}

Perkara gugatan harta bersama merupakan perkara yang sedikit diterima dan diputuskan di Pengadilan Agama Jakarta Selatan dibanding dengan perkara lainnya. Dalam "Laporan Tahunan Pengadilan Agama Jakarta Selatan tahun 2010 tentang Perkara yang

\footnotetext{
${ }^{22}$ Ismuha, Pencaharian Bersama Suami Isteri dari Sudut Undangundang Perkawinan Tahun 1974 dan Hukum Islam, (Jakarta: Bulan Bintang, 1986), h. 296.
} 
Diterima" tercatat ada 2.806 perkara. Dari jumlah perkara tersebut, hanya empat belas perkara yang murni gugatan harta bersama. ${ }^{23}$ Begitu juga, dari 2.788 perkara yang diputus oleh hakim Pengadilan Agama Jakarta Selatan pada tahun 2010, hanya tiga belas yang merupakan putusan perkara harta bersama. ${ }^{24}$ Kondisi demikian tidak jauh berbeda dengan tahuntahun sebelumnya. ${ }^{25}$

Pengajuan perkara gugatan harta bersama dapat dilakukan melalui lima jalur. Pertama, perkara yang murni gugatan harta bersama. Perkara ini dapat diajukan oleh bekas suami atau bekas isteri ke Pengadilan Agama setelah putusan perceraian mereka, baik cerai talak maupun cerai gugat, sudah memiliki kekuatan hukum.

Kedua, gugatan harta bersama kumulasi dengan gugatan cerai yang diajukan oleh isteri. Isteri mengajukan gugatan perceraian sekaligus digabungkan/ dikumulasikan dengan soal penguasaan anak, nafkah anak, mut $a h$, nafkah isteri, dan harta bersama suami isteri.

Ketiga, gugatan harta bersama kumulasi dengan permohonan cerai talak yang diajukan oleh suami. Suami mengajukan permohonan perceraian sekaligus digabungkan/diakumulasikan dengan soal penguasaan anak, nafkah anak, mut ah, nafkah isteri, dan harta bersama suami isteri. ${ }^{26}$

Keempat, isteri mengajukan gugat rekonpensi ketika suami mengajukan cerai talak. Ketika isteri selaku termohon mengajukan jawaban atas dalil-dalil suami selaku pemohon, isteri sekaligus juga dapat mengajukan gugat balik (rekonpensi) terhadap suami terkait dengan soal penguasaan anak, nafkah anak, mut ah, nafkah isteri, dan harta bersama suami isteri.

Kelima, suami mengajukan gugat rekonpensi ketika isteri mengajukan cerai gugat. Suami selaku

${ }^{23}$ Arsip Pengadilan Agama Jakarta Selatan tentang Laporan Tahunan: 2010 Pengadilan Agama Jakarta Selatan tentang Perkara yang Diterima.

${ }_{24}$ Arsip Pengadilan Agama Jakarta Selatan tentang Laporan Tahunan: 2010 Pengadilan Agama Jakarta Selatan tentang Perkara yang Diputus.

${ }^{25}$ Pada tahun 2008, contohnya, diperoleh data bahwa hakim Pengadilan Agama Jakarta Selatan telah memutus 2197 perkara. Putusan yang paling banyak adalah terkait perkara cerai gugat yaitu sejumlah 1114 putusan, kemudian disusul oleh perkara cerai talak berjumlah 527 putusan, sedangkan perkara harta bersama hanya berjumlah 10 (sepuluh) putusan. Lebih lengkapnya lihat Laporan Tahun 2008 Pengadilan Agama Jakarta Selatan tentang Perkara yang Diputus.

${ }^{26}$ Pada Pasal 66 ayat [5] UU Nomor 7 Tahun 1989 tentang Peradilan Agama ditegaskan, "Permohonan soal penguasaan anak, nafkah anak, nafkah istri, dan harta bersama suami istri dapat diajukan bersama-sama dengan permohonan cerai talak". tergugat mengajukan jawaban atas dalil-dalil isteri selaku penggugat, kemudian suami sekaligus juga dapat mengajukan gugat balik (rekonpensi) terhadap isteri terkait dengan soal penguasaan anak, nafkah anak, mut ah, nafkah isteri, dan harta bersama suami isteri. ${ }^{27}$

Salinan putusan hakim Pengadilan Agama Jakarta Selatan yang dijadikan sampel penelitian ini berjumlah enam belas salinan putusan, yang terdiri atas enam salinan putusan perkara gugat harta bersama murni, delapan salinan putusan perkara harta bersama yang diakumulasi dengan gugat cerai oleh isteri, dan dua salinan putusan perkara harta bersama yang diakumulasi dengan permohonan cerai talak oleh suami. Untuk mendapatkan gambaran singkat dari salinan putusan tersebut dapat dilihat dari tabel berikut:

Tabel 1

Pengajuan Gugatan Harta Bersama

di Pengadilan Agama Jakarta Selatan Tahun 2010

\begin{tabular}{|c|c|c|c|}
\hline No & Nomor Putusan & $\begin{array}{l}\text { Tanggal } \\
\text { Diputus }\end{array}$ & $\begin{array}{c}\text { Jalur } \\
\text { Gugatan }\end{array}$ \\
\hline 1 & $\begin{array}{l}\text { 1414/Pdt.G/2009/ } \\
\text { PAIS }\end{array}$ & $6 \operatorname{Jan} 2010$ & $\begin{array}{l}\text { Kumulasi } \\
\text { Cerai Gugat }\end{array}$ \\
\hline 2 & $\begin{array}{l}\text { 2011/Pdt.G/2009/ } \\
\text { PAJS }\end{array}$ & 21 Jan 2010 & $\begin{array}{l}\text { Kumulasi } \\
\text { Cerai Gugat }\end{array}$ \\
\hline 3 & $\begin{array}{l}\text { 891/Pdt.G/2009/ } \\
\text { PAIS }\end{array}$ & $26 \operatorname{Jan} 2010$ & $\begin{array}{l}\text { Kumulasi } \\
\text { Cerai Talak }\end{array}$ \\
\hline 4 & $\begin{array}{l}\text { 2101/Pdt.G/2009/ } \\
\text { PAJS }\end{array}$ & 11 Feb 2010 & Murni \\
\hline 5 & $\begin{array}{l}\text { 2432/Pdt.G/2009/ } \\
\text { PAJS }\end{array}$ & 18 Feb2010 & Murni \\
\hline 6 & $\begin{array}{l}\text { 0503/Pdt.G/2010/ } \\
\text { PAJS }\end{array}$ & 11 Mei 2010 & $\begin{array}{l}\text { Kumulasi } \\
\text { Cerai Gugat }\end{array}$ \\
\hline 7 & $\begin{array}{l}\text { 0937/Pdt.G/2010/ } \\
\text { PAJS }\end{array}$ & 15 Juni 2010 & $\begin{array}{l}\text { Kumulasi } \\
\text { Cerai Gugat }\end{array}$ \\
\hline 8 & $\begin{array}{l}\text { 1297/Pdt.G/2010/ } \\
\text { PAJS }\end{array}$ & 7 Juli 2010 & Murni \\
\hline 9 & $\begin{array}{l}\text { 0914/Pdt.G/2009/ } \\
\text { PAJS }\end{array}$ & 8 Juli 2010 & Murni \\
\hline 10 & $\begin{array}{l}\text { 0972/Pdt.G/2010/ } \\
\text { PAJS }\end{array}$ & 13 juli 2010 & $\begin{array}{l}\text { Kumulasi } \\
\text { Cerai Gugat }\end{array}$ \\
\hline 11 & $\begin{array}{l}\text { 0899/Pdt.G/2010/ } \\
\text { PAIS }\end{array}$ & 21 Juli 2010 & $\begin{array}{l}\text { Kumulasi } \\
\text { CeraiTalak }\end{array}$ \\
\hline 12 & $\begin{array}{l}\text { 1978/Pdt.G/2009/ } \\
\text { PAJS }\end{array}$ & 26 Juli 2010 & $\begin{array}{l}\text { Kumulasi } \\
\text { Cerai Gugat }\end{array}$ \\
\hline 13 & $\begin{array}{l}\text { 1375/Pdt.G/2010/ } \\
\text { PAJS }\end{array}$ & 26 juli 2010 & $\begin{array}{l}\text { Kumulasi } \\
\text { Cerai Gugat }\end{array}$ \\
\hline 14 & $\begin{array}{l}\text { 1318/Pdt.G/2010/ } \\
\text { PAJS }\end{array}$ & $\begin{array}{l}31 \text { Agus } \\
2010\end{array}$ & Murni \\
\hline 15 & $\begin{array}{l}\text { 1825/Pdt.G/2009/ } \\
\text { PAJS }\end{array}$ & 12 Okt 2010 & Murni \\
\hline 16 & $\begin{array}{l}\text { 0618/Pdt.G/2010/ } \\
\text { PAJS }\end{array}$ & 14 Des 2010 & $\begin{array}{l}\text { Kumulasi } \\
\text { Cerai Gugat }\end{array}$ \\
\hline
\end{tabular}

Sumber: Diolah dari data lapangan 2011

${ }^{27} \mathrm{Hal}$ ini didasarkan pada pasal 132 a dan b HIR atau pasal 157 dan 158 RBG, dan ini juga dibenarkan oleh hukum acara Pengadilan Agama. 
Dari sampel data yang diteliti, diketahui bahwa gugatan harta bersama di Pengadilan Agama Jakarta Selatan tidak hanya terjadi pada pasangan suami isteri yang dulu sama-sama bekerja di wilayah publik dan mereka sama-sama menghasilkan uang untuk keluarga, melainkan juga terjadi pada pasangan yang sumber keuangan keluarga mereka dulu hanya dihasilkan oleh salah satu pihak saja. Bahkan, dari salinan putusan yang dijadikan sampel ditemukan data bahwa justru pihak yang tidak ikut bekerja di wilayah publik-yang tentu secara finansial tidak menjadi sumber penghasilan keuangan keluarga-yang lebih banyak proaktif melakukan gugatan harta bersama. Berikut tabel yang memuat kesimpulan peneliti tentang hal tersebut.

Tabel 2

Gugatan Harta Bersama di Pengadilan Agama Jakarta Selatan Tahun 2010

\begin{tabular}{|c|c|c|c|}
\hline No & Nomor Putusan & $\begin{array}{l}\text { Tanggal } \\
\text { Diputus }\end{array}$ & $\begin{array}{c}\text { Penggugat } \& \\
\text { Tergugat }\end{array}$ \\
\hline 1 & $\begin{array}{l}\text { 1414/ } \\
\text { Pdt.G/2009/PAJS }\end{array}$ & $\begin{array}{l}6 \text { Jan } \\
2010\end{array}$ & $\begin{array}{l}\text { Isteri tidak bekerja } \\
\text { gugat suami bekerja }\end{array}$ \\
\hline 2 & $\begin{array}{l}\text { 2011/ } \\
\text { Pdt.G/2009/PAJS }\end{array}$ & $\begin{array}{l}21 \text { Jan } \\
2010 \\
\end{array}$ & $\begin{array}{l}\text { Isteri bekerja gugat } \\
\text { suami bekerja }\end{array}$ \\
\hline 3 & $\begin{array}{l}\text { 891/Pdt.G/2009/ } \\
\text { PAJS }\end{array}$ & $\begin{array}{l}26 \text { Jan } \\
2010\end{array}$ & $\begin{array}{l}\text { Suami bekerja gugat } \\
\text { isteri bekerja }\end{array}$ \\
\hline 4 & $\begin{array}{l}\text { 2101/ } \\
\text { Pdt.G/2009/PAJS }\end{array}$ & $\begin{array}{l}11 \text { Feb } \\
2010\end{array}$ & $\begin{array}{l}\text { Isteri bekerja gugat } \\
\text { suami bekerja }\end{array}$ \\
\hline 5 & $\begin{array}{l}\text { 2432/ } \\
\text { Pdt.G/2009/PAJS }\end{array}$ & $\begin{array}{l}18 \\
\text { Feb2010 }\end{array}$ & $\begin{array}{l}\text { Isteri tidak bekerja } \\
\text { gugat suami bekerja }\end{array}$ \\
\hline 6 & $\begin{array}{l}\text { 0503/ } \\
\text { Pdt.G/2010/PAJS }\end{array}$ & $\begin{array}{l}11 \text { Mei } \\
2010\end{array}$ & $\begin{array}{l}\text { Isteri bekerja gugat } \\
\text { suami bekerja }\end{array}$ \\
\hline 7 & $\begin{array}{l}\text { 0937/ } \\
\text { Pdt.G/2010/PAJS }\end{array}$ & $\begin{array}{l}15 \text { Juni } \\
2010\end{array}$ & $\begin{array}{l}\text { Isteri tidak bekerja } \\
\text { gugat suami bekerja }\end{array}$ \\
\hline 8 & $\begin{array}{l}\text { 1297/ } \\
\text { Pdt.G/2010/PAJS }\end{array}$ & $\begin{array}{l}7 \text { Juli } \\
2010\end{array}$ & $\begin{array}{l}\text { Suami bekerja gugat } \\
\text { isteri bekerja }\end{array}$ \\
\hline 9 & $\begin{array}{l}\text { 0914/ } \\
\text { Pdt.G/2009/PAJS }\end{array}$ & $\begin{array}{l}8 \text { Juli } \\
2010\end{array}$ & $\begin{array}{l}\text { Isteri tidak bekerja } \\
\text { gugat suami bekerja }\end{array}$ \\
\hline 10 & $\begin{array}{l}\text { 0972/ } \\
\text { Pdt.G/2010/PAJS }\end{array}$ & $\begin{array}{l}13 \text { juli } \\
2010\end{array}$ & $\begin{array}{l}\text { Isteri bekerja gugat } \\
\text { suami bekerja }\end{array}$ \\
\hline 11 & $\begin{array}{l}\text { 0899/ } \\
\text { Pdt.G/2010/PAJS }\end{array}$ & $\begin{array}{l}21 \text { Juli } \\
2010\end{array}$ & $\begin{array}{l}\text { Suami bekerja gugat } \\
\text { isteri tidak bekerja }\end{array}$ \\
\hline 12 & $\begin{array}{l}\text { 1978/ } \\
\text { Pdt.G/2009/PAJS }\end{array}$ & $\begin{array}{l}26 \text { Juli } \\
2010 \\
\end{array}$ & $\begin{array}{l}\text { Isteri bekerja gugat } \\
\text { suami bekerja }\end{array}$ \\
\hline 13 & $\begin{array}{l}\text { 1375/ } \\
\text { Pdt.G/2010/PAJS }\end{array}$ & $\begin{array}{l}26 \text { juli } \\
2010\end{array}$ & $\begin{array}{l}\text { Isteri bekerja gugat } \\
\text { suami bekerja }\end{array}$ \\
\hline 14 & $\begin{array}{l}\text { 1318/ } \\
\text { Pdt.G/2010/PAJS }\end{array}$ & $\begin{array}{l}31 \text { Agus } \\
2010\end{array}$ & $\begin{array}{l}\text { Isteri tidak bekerja } \\
\text { gugat suami bekerja }\end{array}$ \\
\hline 15 & $\begin{array}{l}\text { 1825/ } \\
\text { Pdt.G/2009/PAJS }\end{array}$ & $\begin{array}{l}12 \mathrm{Okt} \\
2010\end{array}$ & $\begin{array}{l}\text { Isteri tidak bekerja } \\
\text { gugat suami bekerja }\end{array}$ \\
\hline 16 & $\begin{array}{l}\text { 0618/ } \\
\text { Pdt.G/2010/PAJS }\end{array}$ & $\begin{array}{l}14 \text { Des } \\
2010\end{array}$ & $\begin{array}{l}\text { Isteri tidak bekerja } \\
\text { gugat suami bekerja }\end{array}$ \\
\hline
\end{tabular}

Sumber: Diolah dari data lapangan 2011
Tabel di atas menggambarkan beberapa hal. Pertama, isteri ikut bekerja dan menghasilkan sumber keuangan keluarga, kemudian isteri melakukan gugatan harta bersama terhadap suami yang juga ikut bekerja sebagai penghasil keuangan keluarga. Ditemukan enam salinan putusan yang termasuk ke dalam gugatan kelompok ini. Kedua, isteri tidak ikut bekerja sehingga dia tidak ikut menjadi sumber penghasil keuangan keluarga secara langsung, tetapi kemudian isteri melakukan gugatan harta bersama terhadap suami yang bekerja. Gugatan model ini dapat ditemukan pada tujuh salinan putusan. Ketiga, suami yang bekerja dan menjadi sumber penghasil tunggal keuangan keluarga menggugat harta bersama terhadap isteri yang tidak bekerja. Perkara yang demikian hanya ditemukan pada satu salinan putusan saja. Keempat, suami yang bekerja melakukan gugatan harta bersama terhadap isteri yang juga bekerja. Salinan putusan yang dikategorikan ke dalam kelompok ini berjumlah dua perkara.

Secara teoretis, seperti telah diuraikan terdahulu, diketahui bahwa aturan-aturan yang dimuat dalam KHI tentang harta bersama menghendaki pembagian yang adil bagi suami dan istri dengan membagi dua sama besar, ${ }^{28}$ terlepas dari siapa yang mengajukan gugatan harta bersama dan siapa pula yang mengusahakan harta bersama tersebut. Namun demikian, keadilan yang diharapkan oleh KHI dengan membagi sama besar terhadap harta bersama belum tentu dirasakan adil oleh pihak yang berperkara. Sebab, tidak dapat dimungkiri bahwa sekalipun KHI tidak memperhatikan harta tersebut, upaya siapa dan atas nama siapa, dalam kenyataannya di masyarakat masih banyak yang tidak bisa melepaskan jasa-jasanya selama perkawinan. Sikap itulah yang memicu perselisihan dan perasaan "dirugikan" dengan adanya pembagian harta bersama tersebut.

Oleh karena itu, bagaimana hakim Pengadilan Agama Jakarta Selatan menyikapi berbagai kasus gugatan harta bersama yang diajukan kepada mereka? Apakah ketentuan pembagian harta bersama dalam KHI itu digunakan secara mutlak-dalam arti semua kasus harta bersama diselesaikan dengan pembagian fifty-fifty — atau memang ada solusi lain yang ditawarkan majelis hakim, misalnya dengan memberikan porsi lebih besar kepada pihak suami/istri yang memberikan sumbangsih pekerjaan yang lebih banyak. Untuk menjawab pertanyaan itu, sampel dari putusan hakim Pengadilan Agama Jakarta Selatan tentang harta bersama tahun 2010, akan dianalisis dan klasifikasikan

\footnotetext{
${ }_{28} \mathrm{Hal}$ ini diatur dalam KHI pasal 97, "Janda atau duda cerai hidup masing-masing berhak seperdua dari harta bersama sepanjang tidak ditentukan lain dalam perjanjian perkawinan.”
} 
ke dalam beberapa fokus pembahasan berikut ini.

Pertama, kasus isteri bekerja menggugat suami bekerja. Kasus untuk gugatan yang diajukan oleh isteri yang ikut andil bekerja terhadap suami yang juga bekerja berjumlah sebanyak enam putusan, sebagaimana ditunjukkan dalam tabel berikut:

\section{Tabel 3}

Putusan Gugatan Harta Bersama

di Pengadilan Agama Jakarta Selatan Tahun 2010

dalam Kasus Isteri Bekerja Menggugat Suami Bekerja

\begin{tabular}{|c|c|c|c|}
\hline No & Nomor Putusan & $\begin{array}{l}\text { Tanggal } \\
\text { Diputus }\end{array}$ & Putusan \\
\hline 1 & $\begin{array}{l}\text { 2011/Pdt.G/2009/ } \\
\text { PAJS }\end{array}$ & $\begin{array}{l}21 \mathrm{Jan} \\
2010\end{array}$ & $\begin{array}{l}\text { Damai, sepakat } \\
\text { bagian } 50 \% \text { : } \\
50 \%\end{array}$ \\
\hline 2 & $\begin{array}{l}\text { 2101/Pdt.G/2009/ } \\
\text { PAJS }\end{array}$ & $\begin{array}{l}11 \mathrm{Feb} \\
2010\end{array}$ & $\begin{array}{l}\text { N.O karena } \\
\text { putusan cerai } \\
\text { talak masih } \\
\text { banding }\end{array}$ \\
\hline 3 & $\begin{array}{l}\text { 0503/Pdt.G/2010/ } \\
\text { PAJS }\end{array}$ & $\begin{array}{l}11 \text { Mei } \\
2010\end{array}$ & $\begin{array}{l}\text { Damai, sepakat } \\
\text { dihibah } \\
\text { untuk anak }\end{array}$ \\
\hline 4 & $\begin{array}{l}\text { 0972/Pdt.G/2010/ } \\
\text { PAJS }\end{array}$ & $\begin{array}{l}13 \text { Juli } \\
2010\end{array}$ & $\begin{array}{l}\text { Dibagi dua sama } \\
\text { banyak }\end{array}$ \\
\hline 5 & $\begin{array}{l}\text { 1978/Pdt.G/2009/ } \\
\text { PAJS }\end{array}$ & $\begin{array}{l}26 \text { Juli } \\
2010\end{array}$ & $\begin{array}{l}\text { Dibagi dua sama } \\
\text { banyak }\end{array}$ \\
\hline 6 & $\begin{array}{l}\text { 1375/Pdt.G/2010/ } \\
\text { PAJS }\end{array}$ & $\begin{array}{l}26 \text { Juli } \\
2010\end{array}$ & $\begin{array}{l}\text { Damai, sepakat } \\
\text { menentukan } \\
\text { peruntukan } \\
\text { pembagian harta }\end{array}$ \\
\hline
\end{tabular}

Sumber: Diolah dari data lapangan 2011

Dari keenam putusan di atas diketahui bahwa ketentuan KHI yang mengatur kasus harta bersama diselesaikan dengan pembagian fifty-fifty ternyata tidak digunakan oleh hakim secara mutlak. Hal ini tampak jelas pada Putusan Nomor 2011/Pdt.G/2009/PAJS, Putusan Nomor 0503/Pdt.G/2010/PAJS, dan Putusan Nomor 1375/Pdt.G/2010/PAJS yang berisi perkara gugatan harta bersama diajukan oleh isteri bekerja terhadap suami bekerja itu diselesaikan secara damai. Dalam hal ini, hakim Pengadilan Agama Jakarta Selatan tidak mewajibkan pembagian dengan porsi fifty-fifty, melainkan hanya memutuskan dan menghukum kedua belah pihak yang berperkara untuk mentaati persetujuan yang telah disepakati dalam akta perdamaian. Padahal dalam akta perdamaian itu pembagian harta bersama tidak dilakukan fifty-fifty.

Kedua, kasus isteri tidak bekerja menggugat suami bekerja. Dari sampel salinan putusan, ditemukan sebanyak tujuh salinan putusan yang terkait dengan isteri tidak ikut bekerja sehingga dia tidak ikut menjadi sumber penghasil keuangan keluarga secara langsung tetapi kemudian isteri melakukan gugatan harta bersama terhadap suami yang bekerja. Dalam tujuh salinan putusan tersebut, sebagaimana terdapat dalam tabel di bawah, tampak bahwa hakim Pengadilan Agama tidak mutlak melakukan pembagian fifty-fifty dalam kasus gugatan harta bersama oleh isteri yang tidak bekerja terhadap suami yang bekerja. Dalam beberapa kasus, hakim memutuskan bahwa jumlah porsi harta bersama yang akan diterima oleh para pihak yang bersengketa disesuaikan dengan jumlah porsi yang sudah mereka sepakati berdua.

Tabel 4

Putusan Gugatan Harta Bersama di Pengadilan Agama Jakarta Selatan Tahun 2010 dalam Kasus Isteri tidak Bekerja Menggugat Suami Bekerja

\begin{tabular}{|c|c|c|c|}
\hline No & Nomor Putusan & $\begin{array}{l}\text { Tanggal } \\
\text { Diputus }\end{array}$ & Putusan \\
\hline 1 & $\begin{array}{l}\text { 1414/ } \\
\text { Pdt.G/2009/PAJS }\end{array}$ & 6 Jan 2010 & $\begin{array}{l}\text { Dibagi dua sama } \\
\text { banyak }\end{array}$ \\
\hline 2 & $\begin{array}{l}\text { 2432/ } \\
\text { Pdt.G/2009/PAJS }\end{array}$ & 18 Feb2010 & $\begin{array}{l}\text { Dibagi dua sama } \\
\text { banyak }\end{array}$ \\
\hline 3 & $\begin{array}{l}\text { 0937/ } \\
\text { Pdt.G/2010/PAJS }\end{array}$ & $\begin{array}{l}15 \text { Juni } \\
2010\end{array}$ & $\begin{array}{l}\text { Damai, sepakat } \\
\text { menentukan } \\
\text { peruntukan } \\
\text { pembagian harta }\end{array}$ \\
\hline 4 & $\begin{array}{l}\text { 0914/ } \\
\text { Pdt.G/2009/PAJS }\end{array}$ & 8 Juli 2010 & $\begin{array}{l}\text { Dibagi dua sama } \\
\text { banyak }\end{array}$ \\
\hline 5 & $\begin{array}{l}\text { 1318/ } \\
\text { Pdt.G/2010/PAJS }\end{array}$ & $\begin{array}{l}31 \text { Agus } \\
2010\end{array}$ & $\begin{array}{l}\text { Damai, sepakat } \\
\text { bagian isteri } 40 \% \\
\& \text { suami } 60 \%\end{array}$ \\
\hline 6 & $\begin{array}{l}\text { 1825/ } \\
\text { Pdt.G/2009/PAJS }\end{array}$ & $\begin{array}{l}12 \mathrm{Okt} \\
2010\end{array}$ & $\begin{array}{l}\text { Damai, sepakat } \\
\text { menentukan } \\
\text { peruntukan } \\
\text { pembagian harta }\end{array}$ \\
\hline 7 & $\begin{array}{l}\text { 0618/ } \\
\text { Pdt.G/2010/PAJS }\end{array}$ & 14 Des 2010 & $\begin{array}{l}\text { Damai, sepakat } \\
\text { bagian 50\%: } 50 \%\end{array}$ \\
\hline
\end{tabular}

Sumber: Diolah dari data lapangan 2011

Tabel di atas menggambarkan bahwa dalam kasus isteri tidak bekerja — dan hanya suami yang bekerja, selama tidakada kesepakatan perdamaian diantara pihakpihak yang berperkara, pembagian harta bersama tetap diselesaikan dengan porsi fifty-ffty. Hakim Pengadilan Agama Jakarta Selatan tidak menawarkan solusi lain, misalnya memberikan porsi lebih besar kepada pihak suami yang memberikan sumbangsih pekerjaan yang lebih banyak. Putusan hakim yang memberikan porsi fifty-fifty terdapat pada salinan Putusan Nomor 1414/ Pdt.G/2009/PAJS, Putusan Nomor 2432/Pdt.G/2009/ PAJS, dan Putusan Nomor 0914/Pdt.G/2009/PAJS.

Selain menerapkan pembagian fifty-fifty, dari ketujuh perkara yang dianalisis tentang gugatan harta bersama oleh isteri yang tidak bekerja terhadap suami yang bekerja tampak bahwa hakim Pengadilan Agama Jakarta Selatan juga menentukan bagian yang akan diterima oleh pihak-pihak yang bersengketa itu disesuaikan dengan hasil kesepakatan/Akta Perdamaian yang dibuat oleh kedua pihak. Pembagian yang demikian dapat dilihat pada salinan Putusan Nomor 0937/Pdt.G/2010/PAJS, Putusan Nomor 1318/Pdt.G/2010/PAJS, Putusan 
Nomor 1825/Pdt.G/2009/PAJS, dan Putusan Nomor 0618/Pdt.G/2010/PAJS.

Meski harta bersama yang digugat oleh isteri yang tidak bekerja terhadap suami bekerja pada empat salinan putusan di atas sama-sama dibagi berdasarkan kesepakatan/perdamaian yang dibuat oleh para pihak yang bersengketa, terdapat perbedaan porsi yang akan diterima oleh masing-masing pihak. Sebab, jumlah porsi yang diterima itu tergantung kepada isi kesepakatan mereka.

Pada salinan Putusan Nomor 0937/Pdt.G/2010/ PAJS dan Putusan Nomor 1825/Pdt.G/2009/PAJS, para pihak sepakat mengakhiri sengketa harta bersama dengan langsung menentukan harta benda mana saja yang akan diserahkan kepada pihak isteri dan suami. Mereka sepakat tidak menguangkan harta bersama yang mereka miliki, tetapi langsung saja membagibaginya berdasarkan kesepakatan berdua. Dalam kasus ini, majelis hakim memutuskan dan menghukum penggugat dan tergugat untuk mentaati isi kesepakatan yang sudah mereka buat itu.

Sedangkan dalam kasus Putusan Nomor 1318/ Pdt.G/2010/PAJS para pihak sepakat mengakhiri persengketaan harta bersama itu dengan cara menjual seluruh aset harta bersama yang mereka miliki, dan kemudian membagi hasil penjualannya itu tidak dengan porsi fifty-fifty, melainkan bekas suami mendapatkan bagian $60 \%$ dan bekas isteri mendapatkan bagian $40 \%$ dari hasil penjualan setelah dikurangi dari biaya-biaya atau pajak yang timbul.

Adapun pada kasus yang terdapat pada salinan Putusan Nomor 0618/Pdt.G/2010/PAJS, para pihak sepakat membagi harta bersama yang mereka miliki dengan dua cara. Untuk sebagian harta bersama, mereka bagi-bagi langsung dengan menentukan harta benda mana saja yang akan diserahkan kepada masingmasing pihak dan untuk sebagian harta bersama yang lain mereka sepakat untuk menjualnya, kemudian hasil penjualannya itu dibagi dua sama besar nilainya oleh para pihak.

Dari enam belas sampel penelitian, ditemukan hanya dua salinan putusan yang terkait dengan suami yang bekerja melakukan gugatan harta bersama terhadap isteri yang juga bekerja, yaitu salinan Putusan Nomor 891/Pdt.G/2009/PAJS dan Putusan Nomor 1297/Pdt.G/2010/PAJS. Dalam dua kasus ini, majelis hakim Pengadilan Agama Jakarta Selatan memutus perkara pembagian harta bersama berdasarkan pada Surat Perjanjian yang dibuat oleh kedua belah pihak. Majelis hakim berpendapat bahwa perjanjian tersebut berlaku sebagai hukum bagi masing-masing pihak yang membuatnya. Hal ini sesuai dengan ketentuan pasal 1338 KUHPerdata. Oleh karena itu, majelis hakim menghukum pemohon dan termohon untuk membagi harta bersama yang mereka miliki sesuai dengan jumlah dan cara yang sudah disepakati dalam isi surat perjanjian dimaksud. Hakim tidak melakukan pembagian fiftyfifty untuk masing-masing pihak tersebut.

Ketiga, kasus suami bekerja menggugat isteri tidak bekerja. Kasus suami yang bekerja dan menjadi sumber penghasil tunggal keuangan keluarga menggugat harta bersama terhadap isteri yang tidak bekerja hanya ditemukan pada 1 salinan putusan saja, yakni Putusan Nomor 0899/Pdt.G/2010/PAJS. Pada kasus ini, seorang suami (38 tahun, dokter) mengajukan permohonan cerai talak terhadap isterinya (24 tahun, ibu rumah tangga). Dalam permohonan cerai talak tersebut, suami juga mengkumulasikan dengan persoalan pembagian harta bersama. Dengan memperlihatkan Surat Kesepakatan Bersama yang ditandatangani oleh Pemohon dan Termohon tertanggal 14 Juli 2010 kepada hakim di persidangan, suami menyatakan bahwa terhadap harta kekayaan yang diperoleh selama perkawinan pemohon dan termohon telah sepakat untuk tidak ada pembagian harta bersama. Namun demikian, pemohon bersedia menyerahkan satu unit mobil Honda Type Jazz berikut surat-suratnya. Oleh karena telah terjadi kesepakatan perdamaian antara pemohon dan termohon tentang akibat perceraian, majelis hakim tidak lagi melakukan pembagian harta bersama dengan porsi fifty-fifty, melainkan majelis hakim memerintahkan dan menghukum kedua belah pihak untuk menaati isi Akta Perdamaian tersebut.

Setelah mempelajari tiga kasus yang disebutkan terdahulu tentang suami yang mengajukan gugatan harta bersama, baik yang gugatan murni maupun yang kumulatif dengan cerai talak, tampak bahwa majelis hakim tidak menerapkan ketentuan yang termuat dalam KHI bahwa harta bersama harus dibagi sama banyak. Hal ini dilakukan oleh majelis hakim karena terdapatnya surat kesepakatan perdamaian yang dibuat oleh kedua belah pihak. Putusan hakim dalam ketiga kasus harta bersama itu digambarkan dalam tabel berikut.

Tabel 5

Putusan Gugatan Harta Bersama

di Pengadilan Agama Jakarta Selatan Tahun 2010 dalam Kasus Suami Bekerja Menggugat Isteri

\begin{tabular}{|c|c|c|c|c|}
\hline No & $\begin{array}{l}\text { Nomor } \\
\text { Putusan }\end{array}$ & $\begin{array}{l}\text { Tanggal } \\
\text { Diputus }\end{array}$ & $\begin{array}{l}\text { Penggugat } \\
\& \text { Tergugat }\end{array}$ & Putusan \\
\hline 1 & $\begin{array}{l}891 / \\
\text { Pdt.G/2009/ } \\
\text { PAJS }\end{array}$ & $\begin{array}{l}26 \\
\text { Januari } \\
2010\end{array}$ & $\begin{array}{l}\text { Suami } \\
\text { bekerja } \\
\text { gugat isteri } \\
\text { bekerja }\end{array}$ & $\begin{array}{l}\text { Damai, } \\
\text { sepakat isteri } \\
\text { mendapat } \\
\text { sejumlah uang }\end{array}$ \\
\hline 2 & $\begin{array}{l}1297 / \\
\text { Pdt.G/2010/ } \\
\text { PAJS }\end{array}$ & $\begin{array}{l}7 \text { Juli } \\
2010\end{array}$ & $\begin{array}{l}\text { Suami } \\
\text { bekerja } \\
\text { gugat isteri } \\
\text { bekerja }\end{array}$ & $\begin{array}{l}\text { Damai, } \\
\text { sepakat } \\
\text { menentukan } \\
\text { peruntukan } \\
\text { pembagian } \\
\text { harta }\end{array}$ \\
\hline
\end{tabular}




\begin{tabular}{|c|c|c|c|c|}
\hline 3 & $\begin{array}{l}0899 / \\
\text { Pdt.G/2010/ } \\
\text { PAJS }\end{array}$ & $\begin{array}{l}21 \text { Juli } \\
2010\end{array}$ & $\begin{array}{l}\text { Suami } \\
\text { bekerja } \\
\text { gugat } \\
\text { isteri tidak } \\
\text { bekerja }\end{array}$ & $\begin{array}{l}\text { Damai, } \\
\text { sepakat } \\
\text { menentukan } \\
\text { peruntukan } \\
\text { pembagian } \\
\text { harta }\end{array}$ \\
\hline
\end{tabular}

Sumber: Diolah dari data lapangan 2011

\section{Upaya Hakim dalam Pelaksanaan Pembagian Harta Bersama}

Pada dasarnya, para hakim yang mengadili perkara sengketa harta bersama di Pengadilan Agama Jakarta Selatan telah menggunakan ketentuan KHI sebagai rujukan dalam menetapkan putusannya. Dari enam belas putusan yang dijadikan sampel penelitian ini diketahui bahwa selama tidak ada kesepakatan damai oleh para pihak yang bersengketa maka putusan pembagian harta bersama tidak keluar dari aturan KHI yang menghendaki pembagian yang adil bagi suami dan isteri dengan membagi dua sama banyak, terlepas dari siapa yang mengusahakan harta bersama tersebut dan juga tidak memperhatikan kepemilikan harta bersama tersebut terdaftar atas nama siapa. Majelis hakim telah berupaya melakukan pembagian harta bersama secara adil, baik dalam kasus suami isteri yang sama-sama bekerja maupun salah satu pihak yang bekerja.

Ketika kasus gugatan harta bersama itu terjadi pada pasangan yang selama dalam perkawinan mereka itu pihak isteri tidak terlibat bekerja yang menghasilkan uang, para hakim tetap menilai dengan adil bahwa pekerjaan isteri di dalam rumah tangga dalam bentuk mengelola rumah tangga sebanding dengan suami yang bekerja di luar rumah. Menurut mereka, peran isteri sebagai ibu rumah tangga memberi kontribusi penting dalam proses perolehan harta bersama. Dalam konteks ini dipandang sebagai keadilan bila majelis hakim memutuskan isteri mendapat bagian yang sama dengan suami.

Hanya saja, peneliti tidak menemukan satu salinan putusanpun untuk dijadikan sampel dalam kasus isteri yang bekerja sedangkan suami tidak bekerja. Dengan demikan, peneliti tidak memiliki data untuk menilai bagaimana hakim melakukan pembagian harta bersama jika suami tidak bekerja, sedangkan isteri menjalankan peran ganda sebagai pengelola rumah tangga dan sekaligus pencari nafkah keluarga. Hal ini patut dipertanyakan karena dalam banyak kasus, ketika isteri bekerja di luar rumah, sangat jarang suami mengambil alih pekerjaan rumah tangga. Dalam konteks ini, menurut peneliti, adalah tidak adil apabila harta bersama tetap dibagi sama banyak. Sejatinya, dalam kasus yang demikian adalah adil apabila isteri mendapat bagian harta bersama yang lebih banyak dibanding bagian suaminya.

Dalam beberapa sampel salinan putusan, hakim juga memutuskan pembagian harta bersama didasarkan atas kesepakatan atau perdamaian yang dibuat oleh pihak suami isteri yang bersengketa. Ketentuan KHI tidak dipraktikkan sebagaimana yang tertulis, tetapi mengambil nilai yang terkandung di dalamnya, yaitu "keadilan". Oleh karena itu, ketentuan pembagian harta bersama dalam KHI bukan merupakan sesuatu yang mutlak dan harus diterapkan untuk semua kasus pembagian harta bersama, melainkan hanya dijadikan sebagai gambaran umum oleh para hakim dalam menyelesaikan dan memutus perkara pembagian harta bersama. Para hakim dapat lebih fleksibel tergantung kasus yang terjadi. Pembagian harta bersama dengan cara berdamai ini merupakan salah satu solusi yang lebih menjamin tercapainya putusan yang adil sesuai dengan harapan para pihak yang bersengketa.

\section{Penutup}

Studi ini menghasilkan temuan bahwa secara umum perundang-undangan di Indonesia telah mengatur tentang pelembagaan harta bersama. Yang dimaksud dengan pelembagaan harta bersama adalah penyatuan harta yang diperoleh selama dalam perkawinan untuk menjadi harta berdua suami dan isteri, tanpa menghiraukan siapa yang bekerja dan harta itu terdaftar atas nama siapa. Apabila hubungan perkawinan suami isteri berakhir baik karena kematian maupun karena perceraian, maka harta tersebut harus dibagi.

Hal ini berbeda dengan rumusan hukum Islam yang di-istinbath-kan oleh fukaha mazhab. Kitab-kitab fikih klasik tidak mengatur tentang pelembagaan harta bersama suami isteri. Menurut fukaha mazhab, suami memiliki hartanya sendiri dan isteri juga memiliki hartanya sendiri. Sebagai kewajibannya, suami memberikan sebagian hartanya itu kepada isterinya atas nama nafkah, yang untuk selanjutnya digunakan isteri bagi keperluan rumahtangganya.

Secara umum, para hakim yang mengadili perkara sengketa harta bersama di Pengadilan Agama Jakarta Selatan telah menggunakan KHI sebagai rujukan dalam menetapkan putusannya. Dari enam belas putusan yang dijadikan sampel dalam penelitian ini diketahui bahwa putusan pembagian harta bersama tidak keluar dari aturan KHI yang menghendaki pembagian bagi suami dan isteri dengan membagi dua sama banyak nilainya, baik dalam kasus suami dan isteri yang samasama bekerja maupun salah satu pihak yang bekerja.

Selain itu, hakim juga memutuskan pembagian harta bersama didasarkan atas kesepakatan atau perdamaian yang dibuat oleh pihak suami dan isteri. Ketentuan KHI 
secara tekstual tidak dipraktikkan, tetapi spirit keadilan KHI dijadikan landasan putusan. Dengan demikian, ketentuan pembagian harta bersama dalam KHI bukan merupakan sesuatu yang mutlak, melainkan dapat diterapkan dalam kasus-kasus tertentu.

Sebagai akhir tulisan ini dikemukakan sebuah catatan penting yang sekaligus menjadi rekomendasi penelitian bahwa ketentuan mengenai harta bersama dalam peraturan perundang-undangan di Indonesia belum bisa mengkaver pelbagai kasus yang terjadi dewasa ini, sehingga diperlukan amandemen terhadap ketentuan yang termuat dalam Undang-undang Perkainan dan juga KHI. Selanjutnya, karena beratnya tugas dan amanat yang harus diemban Pengadilan Agama, maka para hakim harus terus-menerus meningkatkan kualitas diri sehingga putusan-putusan yang dihasilkan oleh para hakim Pengadilan Agama dapat mengikuti perkembangan masyarakat Indonesia. []

\section{Pustaka Acuan}

Ibn ㅂanbal, al-Imâm Aḥmad, Musnad al-Imâm A $\underline{h} m a d$, Bayrût: Dâr al-Fikr, t.th.

Ibn Qudâmah, al-Mughnî wa Syarh al-Kabîr, Bayrût: Dâr al-Fikr, 1984.

Ismuha, Pencaharian Bersama Suami Isteri dari Sudut UU Perkawinan Tahun 1974 dan Hukum Islam, Jakarta: Bulan Bintang, 1986.
Mughniyah, Muhammad Jawad, al-Fiqh 'alâ alMadzâhib al-Khamsah, Bayrût: Dâr al-Jawad, t.th.

Presiden Republik Indonesia, Inpres Nomor 1 Tahun 1991 (Kompilasi Hukum Islam).

Republik Indonesia, Undang-undang Nomor 1 Tahun 1974 tentang Perkawinan.

----------, Undang-undang Nomor 7 Tahun 1989 tentang Peradilan Agama.

-.---.-----, Undang-undang Nomor 3 Tahun 2006 tentang Perubahan atas Undang-undang Nomor 7 Tahun 1989 tentang Peradilan Agama.

Sarakhsî, al-, Syams al-Dîn, al-Mabsûth, Bayrût: Dâr al-Ma`rûfah, 1989.

Sudiyat, Imam, Hukum Adat; Sketsa Asas, Yogyakarta: Liberty, 1981.

Suyûthî, al-, Jalâl al-din, al-Asybâh wa al-Nazhẩir fi Qawâ'id wa Furû̀ al-Fiqh al-Syâfi' î, (al-Qâhirah: Isa al-Bâbi al- $\underline{\text { Halabi, t.th. }}$

Syâfi'î, al-, Muhammad Idrîs, al-Umm, t.tp: t.p, t.th.

Syarifuddin, Amir, Hukum Perkawinan Islam di Indonesia; Antara Munakahat dan UU Perkawinan, Jakarta: Kencana, 2006.

Tanûkhî, al-, al-Imâm Sahnûn ibn Sa `îd, al-Mudâwanah al-Kubrâ, Bayrût: Dâr Shâdir, 1323 H. 